\title{
Should Publishers and Authors be more responsible?
}

\author{
M. J. Berry \\ Consultant Clinical Forensic Psychologist, \\ Department of Applied Criminology, Birmingham City University, England
}

\begin{abstract}
Should publishers adopt a more responsible role when publishing books that name individuals as killers in major unsolved murder cases? This paper explores what could be described as "trial by authors" and the implications this has for victims; and their families; the alleged offenders and their families and the wider Society. It will use the case of the Hammersmith Nude Murders of six female prostitutes, where six books written by six authors identified five different killers and the implications of their naming potential killers. The sexual murders occurred in and around London's Hammersmith during 1964 to 1965. Nobody was ever convicted. This writer argues that publishers should exercise some control over publishing what would be libellous if the identified individual was still alive.
\end{abstract}

Keywords: publishers' responsibilities; sex workers murders; false allegations; trial by authors; the killer known as 'Jack the Stripper'.

\section{A BRIEF HISTORY OF THE HAMMERSMITH NUDE MURDERS}

Six female prostitutes (sex workers) working the West of London in England during 1964/1965 were murdered by what the police, the mass media and most experts recognise as a serial killer (see British newspapers at the time; for example Daily Mirror [1-2]; and later an article in the Sun Newspaper [3]).

The killer quickly killed his first two victims, stripped them naked and soon afterwards deposited them by the side of London's famous river Thames before killing at least four other prostitutes in the Hammersmith area, who were left at various local sites. The killer was quickly nicknamed "Jack the Stripper" by the media playing on the famous 'Jack the Ripper' series.

A notable aspect of the Hammersmith killer was that he started to keep the victims' bodies for an increasing longer period of time and the last one for almost four weeks following the classic serial killer pattern. The victims' bodies were found covered in fine paint spray which after extensive police searches was tracked to a car spray paint shop on the Heron Trading Estate (a big industrial estate in Acton, a suburb of London). It was next to an electric sub-station where the killer had kept the victims' bodies [4-5].

Approximately 120,000 statements were taken, police women were used as 'decoy' prostitutes and various other tactics were used to attempt to identify the killer [4-5]. At the time it was the largest U.K. police investigation with Police Officer Superintendent John du Rose from Scotland Yard 
running the murder team. He identified Mungo Ireland as the killer after Ireland had committed suicide on the $3^{\text {rd }}$ March 1965 by carbon monoxide poisoning in his garage [6]. Apparently Ireland was only employed as security guard for three weeks on the Heron Estate [4]. For various reasons the police never finished interviewing some 7,000 people working or connected within the Heron Estate [5].

\section{A REVIEW OF THE BOOKS WRITTEN ABOUT THE MURDERS}

One of the earliest books to be published on the murders was "Laid Bare: The facts behind the Thames-side Murders" [7] written by journalist Brian McConnell in 1974, who died in 2004. He can be regarded as being a proponent of the Police, defending their approach and maintaining that a security guard at the Heron Estate (Mungo Ireland) was the killer. Similarly ex-detective Dick Kirby's [8] "Laid Bare: The Nude Murders and the Hunt for 'Jack the Stripper" written with the apparent aim of not wanting to show police organizational mismanagement and their understandable inability to manage the vast amount of data acquired. He preferred not to identify an individual asking readers to make up their mind reviewing various suspects including the 'disgraced cop' as the most likely suspect. Of interest is the claim by Neil Milkins [9] that Kirby basically plagiarised his book. While Mason [10] "Exposing Jack the Stripper: A Biography of the Worst Serial Killer You've Probably Never Heard of" was a very short book and added little to the subject. Superintendent John du Rose wrote about the Jack the Stripper case [6] without clarifying the situation. Other books published include Seabrook's [4] "Jack of Jumps"; Milkins' [9] "Who was Jack the Stripper?" Litchfield's [11] "The secret life of Freddy Mill" and Jarossi's [5] "The hunt for the $60 s^{\prime}$ Ripper". These books will be examined in more depth.

\section{'Jack of Jumps' (David Seabrook, 2006 [4])}

Seabrook (died 2009), claimed to have had full access to the 1960s police records and pathology reports with the approval of the police. Rather than providing the evidence he claimed to have access to, denied to other journalists, writers and academics, he spent too long decrying the victims making unnecessary and unfounded vulgar comments about the victims and their families.

Seabrook [4] casts doubts upon much of the police investigation and identified the alleged 'disgraced cop' (who remained unnamed) as the killer, apparently he became a serious suspect after sex worker victim number six Bridie O'Hara's death. The 'disgraced cop' was born in 1936 and after conscription joined the Metropolitan Police in 1956, he was appointed a detective in 1961. He was later sentenced to a year in prison and discharged from the police force for separate non sexual/non-violent offences. Seabrook [4] argued that the 'disgraced cop 'was taunting the police by disposing of the victims' bodies in different police divisions and only stopped in April 1965 after boundaries were changed; an unsatisfactory explanation, nevertheless he argued that the killer was still alive in 2006.

\section{Who was Jack the Stripper? (Neil Milkins, 2011 [9])}

Milkins, a retiree from Abertillery, has a lifelong interest in the Harold Jones' case, where in 1921, local fifteen year old Harold Jones murdered eight year old Freda Brunel. Jones had been charged with her murder but was acquitted and returned home to Abertillery in South Wales. However, within five weeks of the trial ending, he killed his second victim eleven year old Florence Little cutting her throat in his family's kitchen and hiding her body in the attic where it was quickly found by the police. 
In October 1921, Harold Jones was found guilty of the murder of Florence Little and was sentenced to the equivalent of a Life Sentence for juvenile offenders. While in prison, he later admitted to the first murder. It would appear that both victims had been sexually assaulted. Florence's murder appears to have been an act of revenge for taunting him about killing Freda. It is presumed that he was sexually aroused because of the sadistic nature of the homicide and the evidence of ejaculation at the time.

Jones was released from prison in December 1941 without any treatment or any risk assessment undertaken [12]. To-day Jones would fail a Parole Hearing and would not have been discharged [13]. However he joined the army and served overseas including North Africa as an engineer, being demobbed in 1946 with a good service record according to his daughter. He moved to London where in August 1948, he married Muriel Widdows (aged 35). He then disappeared under the radar having no police or the Probation Service monitoring or being returned to prison for breaching his Life Licence conditions. He later re-emerged in the 1960s living in London, married with a daughter.

Milkins, self-published his book stating that Jones was responsible for the Hammersmith Nude Murders without any independent supportive evidence other than he was living in London at the time of the murders. Criminologist Kim Rossmo specified two hotspots where the killer was likely to live and where incidentally Jones alleged lived in these area in the 1960s [9]. The publication was not financial or career driven but merely an obsessional interest in the case, yet clearly Milkins has put considerable effort into justifying his "intuition". Being neither a journalist nor academic, Milkins was not constrained by ethical guidelines imposed on journalists, academics or Psychologists; which enabled him to recently 'door stepped' Harold Jones' daughter to inform her of her father's double (1921) murders without any responsibility for the consequences of such behaviour.

\section{The secret life of Freddy Mills (Michael Litchfield [11])}

In the 1960s, Freddy Mills the boxer, a former world champion, was treated with a great deal of reverence by the public and the mass media, a similar phenomenon to Mohammed Ali of a later generation. Nevertheless Litchfield [11] identified Freddie Mills as 'Jack the Stripper' and that he was killed by the Kray Brothers (well-known violent gangsters in London's East End) for killing their prostitutes. They knew Mills because of their well-known love of boxing and their celebrity status on the 'nightclub scene' [14]. However, there was no known negative connection between the victims, Mills and the Kray Brothers. Litchfield padded out his book with stories of his involvement in the criminal world, reporting the two murders Freddy Mills was supposed to have committed in few pages of his book. It is of concern that a journalist can produce a book with so little evidence other than he argued that John du Rose gave fellow Freemason Mills time to sort his affairs out before he would be charged with murder. According to Litchfield, Mills faked his suicide with the assistance of the Kray Brothers to avoid imprisonment.

Mills' method of committing suicide was extremely unusual shooting himself in his eyeball with the bullet passing into his brain, rare but technically possible [4]. The alternative interpretation that the Kray Brothers hired a hitman to commit the murder is challenged by Berry [13] on the basis that a hitman would have completed the murder in a more professional manner with a powerful handgun rather than the borrowed fairground rifle Mills used [13]. There is no evidence to show that Mills received any threats from the Krays, who would have paid a threatening but polite visit, then made 
a verbal threat, then a physically assault with warnings before if necessary arranging the death of an 'offending' individual.

During the Hammersmith murders period, the mass media were obsessed with the 'Profumo Affair' involving U.K. Defence Minister John Profumo [15]. Basically, he was having a sexual relationship with Christina Keller who was also enjoying one with the London based Russian Defence Attaché. Profumo lied in the House of Parliament about his relationship, later confirmed it and resigned under embarrassing circumstances. Litchfield [11] suggested that the second victim had been 'silenced' by the symbolic stuffing her mouth with a pair of knickers being it was claimed a message from very powerful people for certain individuals to be silent in respect of High Society's sexually activities. (The killings predated the development of D.N.A. testing). In the 1960s, prostitute murders would not have received the sympathy that they would today. Litchfield did not explain the death of the other four victims and seems to have exercised his 'artistic licence'.

Almost 200 pages were written before providing any depth about the case and a jumbled storyline built into an unsubstantiated book, causing the Mills' family unnecessary distress regarding the unfounded allegation of Freddy Mills being a serial killer. During a B.B.C. television programme [16], examining Mills' death, Litchfield [17] stated that he "was 80\% confident that Mills was the killer", which was basically used by the television producer to dismiss Litchfield's contribution to the 'Jack the Stripper' investigation. Litchfield [11] appears to have written a headline grabbing book rather than produce a factual piece of work.

\section{The hunt for the 60s' Ripper (Robin Jarossi [5])}

Journalist Jarossi covered the historic issues well and argued that the killer had to have considerable knowledge of the area and the direction of the police investigation; he also argued that the killer may well have been identified by the prostitute Frances Brown's description of one of her customers who identified himself as a police officer. Unlike the other authors who talk of 'a disgraced cop', Jarossi identified Police Superintendent Bill Baldock [5] as a suspect and argued that it is more likely that it was a serving officer. He made some interesting comparisons to other series of serial killings in various countries and explored the role of police officers in committing serial killing worldwide. Jarossi [5] suggested that the killer was actively "hidden in full sight" and only stopped because the investigation was getting close to him. It is of note that he provided a clear review of the murders and it could be argued that it was the least bias of the reviewed books.

\section{DISCUSSION}

The killer's action indicated a sexually sadistic predatory psychopath with links by physical location, victims being sex workers, similar physical victim characteristic, his modus operandi, transportation and storage resulting in escalation of pleasure. Cruelty and murder are committed in order to derive sexual pleasure which appears to be consistent with this case [18]. Sexual sadism is defined under DSM-V as the 'recurrent and intense sexually arousal from physical or psychologically suffering from another person, manifested by fantasies, urges and behaviours' [19]. After the second murder he clearly put in considerable time and effort with the later killings.

The reasons why the murders stopped could be because he became heavily involved in an emotionally satisfying relationship; located elsewhere possibly even overseas; although motives such as marriage; a child's birth or even death; as well as imprisonment; in addition to fearing being 
Berry, M. J. (2020) Should Publishers and Authors be more responsible? Advances in Social Sciences Research Journal, 7(5) 314-322.

caught given two occasions when he could have been identified (see [9], [5] should all be considered as possible explanations.

Profiling the killer, BERRY [13] argued the killer "was likely to be 5'6" and above, white, male, employed with flexible working conditions, right handed, employed in London, likely to be living and working weekdays in the areas highlighted [20], comfortable hiring sex workers, with no indication of driven ideology such as political, religious or mental illness". It was anticipated that he would have a history of violent behaviour including domestic violence. It is likely that he would have either been conscripted to the Armed Services or been imprisoned (or both). He may have murdered in response to a relationship failure as offenders are known to restart sexual offending after a relationship break-up. It is highly unlikely he operated with another male killer or a female. See BERRY [13] detailed psychological profile for further explanation.

\section{Possible Suspects}

Harold Jones (1906-1971) committed his first murder aged 15 and would be 58 if he committed the first murder in 1964 with some 43 years since murdering two young girls. His first victim aged eight was tied up her arms behind her back and he cut his eleven year old second victim's throat as an act of revenge yet this behaviour is not repeated in the Hammersmith murders although he did hide his victim's body a pattern shown in the later killings of 'Jack the Stripper'.

An escalation could be expected yet there was no obvious evidence of increased violence, although storing and staging the Stripper's victims' bodies could be perceived as increasing his sadistic behaviour. Apparently in prison, Harold Jones is reported to have said "I do not want to lose the desire to kill" [9], a somewhat worrying aspect of his cognitions. The 'disgrace cop', a high ranking serving police officer, the previously mentioned Mungo Ireland, as well as the man seen with the last prostitute to be killed who was with a friend picking up prostitutes but never came forward when requested by the Police [5], were some of the identified suspects. While Kenneth Archibald claimed to have killed various victims but retracted his confession and was subsequently found not guilty [4, p173]. Superintendent John du Rose (S.I.O.) was criticised for continuing to investigate other suspects for some two months after Mr. Ireland's death, having argued that Ireland committed suicide as he was about to be caught. He could not explain why Ireland would have murdered Bridie O'Hara, the last victim, as he was in Dundee in Scotland the previous day so it is unrealistic to expect him to have travelled down to London to kill a prostitute and then return to Scotland where he was alibied by various people.

Milkins [9] argued Jones was the killer because he lived in the Hammersmith area however so did many other killers. Using British Executions.co.uk data [21], it is estimated that the U.K. had an average of 330 murders between 1947 and 1964s of which 10 are executed. As one in six of the U.K. population reside within the Greater London' boundaries it is assumed that at least one in six discharged killers are likely to live in Greater London so allowing a figure of say 300 released annually then over 50 will end up in Greater London resulting in at least 750 killers in the 1960s, as such being a released killer living in London would not be that exceptional for Harold Jones. Most convicted discharged killers at the time of the killing are aged 45 or less and serve an average of 15 years with Lifers released by 60 could expect a life expectancy of fifteen years or more. However, it is accepted that in the 1960s Harold Jones lived in Hammersmith within the two "hot spots" identified [20]. 
According to du Rose [6], Mungo Ireland committed suicide because he was close to being arrested although his family argue that it was because he could not cope with other issues in his life [5]. However, he did not come to police notice until two months after his death and was in Scotland for Bridie 0'Hare's murder, so he can be rejected. The police had two officers initially regarded as suspects namely the "disgraced cop" and more worrying a very senior police officer Superintendent Butler who had at one time a significant role in the investigations. He was never charged with any murders and died in 1970. Twenty individuals were considered suspects during the investigation which was finally reduced to three suspects [4, p347]; however this did not include Harold Jones or Mungo Ireland.

This writer would argue that a police officer is a valid suspect but not the "Disgraced Cop" mentioned in various books. Because of the large number of police officers involved in the case, it was impossible to identify those directly or indirectly involved with sufficient knowledge about developments to avoid being detected. Nevertheless his behaviour would not initially cause the prostitutes any concern while negotiating business. The male who was last seen with victim Margaret McGowan on the 23 ${ }^{\text {rd }}$ October 1964 and described as aged 30-32, 5'10" tall and driving a light grey car was never interviewed or came forward in response to a Public Appeal.

If in the event it was Harold Jones then he would be 58 at the start of the killing series in 1964 and dead aged 65 of cancer by 1971. Wilson [22, p79] highlighted cases of a repeat murder after serving a Life sentence but not with a gap of 43 years in the case of Harold Jones. Although the Scottish serial killer Peter Tobin (born 1946) committed his first murder aged 44 and his last convicted murder at 60 years old however he had spent 10 years in prison between the first and last and killed within two years of his prison discharge. This writer could not identify a U.K. sexual serial killer starting their series aged 60+. Although, in 2019, Canadian serial killer 67 year old Bruce McArthur was convicted for eight gay male murders over a seven years [23], without evidence of any killings before reaching 60 .

BERRY [13] argued that the killer would be into his 80s in 2020, if correct that the killer was likely to be in his early to mid-30s at the time of the murders. It is likely that the killer would re-offended at a later date unless physically unable to do so because he clearly posed a serious risk to prostitutes and females in general. Of interest it is noted that Denis Rader, the "B.T.K. killer" (bind, torture and kill) killed 10 victims in a series and then was dormant for a decade until there was a conflict over his previous killings so he taunted the police, which eventual led to his capture. However, neither 'Jack the Stripper' or Harold Jones appeared to want attention. 'Jack the Stripper' is not known to have attempted to provoke the police nor contacted the mass media.

It is unlikely that the killer will be convicted unless he makes a voluntary confession, makes a legal declaration to be disclosed after his death or a death bed confession. Davis [24] reported old soldiers experienced P.T.S.D. when nearing death or dementing and recalled the long-time suppressed war memories, the same could happen with this killer. As a clinician, this writer would want to assess him even accepting the difficulties assessing someone experiencing dementia etc. Berry, Robinson and Bailey [25] argued that hypnosis could help a suspected killer to recall details of his actions but have highlighted the difficulties in doing so. 
As to death bed confessions [26] reported the case of a 70-year old terminally ill man who confessed to a doctor, that some 40 years earlier he had been a gang hitman and had killed several individuals and for some their bodies remained still undiscovered. He expressed considerable anxiety about his behaviour. Tincknell et al. [26] explored the ethical, legal and psychological factors in the case with different viewpoints being offered but basically they did not breach confidentiality nor report him to the police [26]. It is understood that he promised to provide data to be provided for the police after his death. Of course the man could have been making a 'false confession' an interpretation not discussed by them.

\section{Effect on families}

Most of the highlighted authors have negatively identified individuals whose family members basically have no protection against the unfair public exposure. The negative effect ripples through extended families, friends and neighbours. 'Googling' one's family history has proved to be disastrous for some individuals who have discovered their relative has been named as a serial killer. Who did it and why and the implication for the victim's families and the community need to be recognised by any writer writing on this type of topic. One of the consequences for family members is discovering that the victim was a working prostitute, having to come to terms that you lost your mother at an early age and then discover that she was actually a murdered prostitute with the killer remaining free which will be stressful for the surviving relatives. Stigmatization is very deep and difficult to reduce even over time.

Many of the writers provided little solid evidence to support their chosen killer with some spending considerable effort reporting on events outside of the actualities of the case. Litchfield [11], spent thousands of words writing about his police informant who acted as his "deep throat" while describing two of the alleged killings in a few pages. As previous mentioned Seabrook [4] wrote about the victims and their families in a very derogative manner and any relative reading his book would be horrified by the contents. This was a book that really did not deserve any attention.

This writer has not reviewed the internet as that is even more unreliable about offences for example a web page on serial killers (https://totalcrime.co.uk, [27] has generated the name of 29 year old Anthony Holland as the killer who later committed suicide. Yet there is no attempt to evidence such a statement. During 2006/2007 the Metropolitan Police carried out a 'Cold Case Review' of the murders but did not identify the killer.

It would appear that some of the writers wrote their books for self-promotion, others were sensation seekers, producers of pulp fiction, on their hobby-horse and occasionally presenting an objective view. Publishers should be more evidence based although this is likely to undermine most writers' approach of making a book appealing to the public. Publishers should ask themselves is it immoral/unethical to publish work that basically puts on trial an individual for murders undertaken over decades before without sufficient access to investigation material and thus allows selfappointed 'experts' to cause damage to dead individuals' families while inconsiderate to the 'ripple effect' on generations of relatives. Ironically, Ian Brady, 'The Moors' serial killer uses the expression "commercial crime scavenger" [28, p51] for crime writer but is also critical of "self-appointed experts but who were practical amateurs". Should publishers be more selective in their acceptance of proposed books about unsolved homicides as the dead cannot sue for libel? The alternative interpretation is that sex sells books!? 


\section{ACKNOWLEDGEMENTS}

As a result of this writer's involvement in the documentary 'Dark Son' [29], a considerable amount of background material was provided by Monster Films of Cardiff.

\section{Conflict of Interest}

The author received financial benefit from appearing as an expert in the 'Dark Son' documentary produced by Monster Films but nevertheless the views expressed are solely those of the author.

\section{References}

1. Daily Mirror (1964). Nude in the River, Friday 1st May 1964.

2. Daily Mirror (1964). Teeth taken, August 1964.

3. Summer, 0. (1972). The Sun newspaper February 1972.

4. Seabrook, D. (2006). Jack of Jumps, London: Granta Publications.

5. Jarossi, R. (2017). The hunt for the 60s' Ripper, London: Mirror Books.

6. du Rose, J. (1971). Murder was My Business, St Albans: Mayflower Books. ISBN 978-0-491-00477-0.

7. McConnell, B. J. (1974). Laid Bare: The facts behind the Thames-side Murders. London: New English Library.

8. Kirby, D, (2016). Laid Bare: The Nude Murders and the Hunt for 'Jack the Stripper, publisher: Stroud: The History Press. ISBN 978-0-750-96625-2.

9. Milkins, N. (2011). Who was Jack the Stripper?, The Hammersmith nude murders. Abertillery, Gwent: Rose Heyworth Press.

10. Mason, F. (2013). Exposing Jack the Stripper: A Biography of the Worst Serial Killer You've Probably Never Heard of, Independent Publisher:

11. Litchfield, M. (2017). The secret life of Freddy Mills. London: John Blake Publishing Ltd.

12. Wilson, D. \& Brookes, M. (2011): Making sense of the sexual sadist between the wars: the case of Harold Jones, Journal of Forensic Psychiatry \& Psychology, DOI: 10.1080/14789949.2011.599852.

13. Berry, M. J. (2020). A Psychological Profile of the Hammersmith Nude Murders, under review.

14. Pearson, J (2011). Notorious: The Immortal Legend of the Kray Twins. London: Random House. p. 51. ISBN 9780099505341.

15. Doward, J. (2020). How MI5 chiefs abandoned Stephen Ward to take the blame in Profumo scandal. The Guardian, Sunday 26th January 2020.

16. British Broadcast Corporation (BBC 2018). "Death of Freddy Mills" Broadcasted on BBC4 on Wednesday 1st August 2018.

17. Litchfield, M. (2018) interview on British Broadcast Corporation (BBC 2018). "Death of Freddy Mills" Broadcasted on BBC4 on 1st August 2018.

18. Proulx, J., Blais, E., \& Beauregard, E. (2006). Sadistic sexual aggressors. In W.L. Marshall, Y.M., Fernandez, L.E. Marshall, \& G.A. Serran (Eds.), Sexual offender treatment: Controversial issues (pp. 61-77). Chichester: John Wiley \& Sons.

19. American Psychiatric Association. (2013). Diagnostic and Statistical Manual of Mental Disorders (5th ed.), Arlington, VA: American Psychiatric Publishing.

20. Rossmo, K. as cited in Milkins, N. (2011). Who was Jack the Stripper?, The Hammersmith nude murders. Abertillery, Gwent: Rose Heyworth Press.

21. British Executions- list of hangings (2020), www.britishexecutions.co.uk. 
Berry, M. J. (2020) Should Publishers and Authors be more responsible? Advances in Social Sciences Research Journal, 7(5) 314-322.

22. Wilson, D. (2007), Serial Killers: Hunting Britons and their victims 1960-2006, Winchester, Dorset: Waterside Press.

23. Sky News (2019). Serial killer Bruce McArthur gets life for killing victims from Toronto's Gay Village (Sky News, Friday 8 February 2019).

24. Davies, S. (1997). The long-term psychological effects of World War Two. The Psychologist, 10, 8, 364-367.

25. Berry, M. J., Robinson, C. \& Bailey, J. (2004). Can Hypnosis Be Used to Recover Evidence from Offenders?: Issues \& Implications. Forensic Update, 79, 11-16.

26. Tincknell, L., O'Callaghan, A., Manning, J. \& Malpas, P. (2018). Deathbed Confession: When a Dying Patient Confesses to Murder: Clinical, Ethical, and Legal Implications. J Clin Ethics. 2018 Fall; 29(3):179-184.

27. Total Crime (2015). Serial Killers https://totalcrime.co.uk/2015/08/03/serial-killers-2/.

28. Brady, I.S. (2001). The Gates of Janus, Los Angeles, CA: Feral House. ISBN:0-922915-73-3.

29. Dark Son (2019) by Monster Films first broadcasted on B.B.C. 4 Sunday 12th January (director by David Howard). 